Review Article

\title{
Diversity of Bacteria from Antarctica, Arctic, Himalayan Glaciers and Stratosphere
}

\author{
SISINTHY SHIVAJI ${ }^{1,2 *}$, MADHAB K CHATTOPADHYAY ${ }^{2}$ and GUNDLAPALLY S REDDY ${ }^{2}$ \\ 'Jhaveri Microbiology Centre, Prof Brien Holden Eye Research Centre, L V Prasad Eye Institute, \\ Hyderabad 500 004, India \\ ${ }^{2}$ CSIR-Centre for Cellular and Molecular Biology, Hyderabad 500 007, India
}

(Received on 03 April 2019; Accepted on 05 October 2019)

\begin{abstract}
This review explores the bacterial diversity of Antarctica, Arctic, Himalayan glaciers and Stratosphere with a view to establish their abundance, their identity and capability to adapt to cold temperatures. It also highlights the unique survival strategies of these psychrophiles at the molecular, cellular, tissue and organism level. It also establishes their utility to mankind in the spheres of health, agriculture and medicine. A major part of the review includes studies carried by scientists in India in the above extreme cold habitats.
\end{abstract}

Keywords: Diversity; Himalayan; Stratosphere; Antarctica

\section{Bacterial abundance of Antarctica, Arctic, Himalayas and Stratosphere}

Antarctica, Arctic and Himalayan regions are considered as highly arid, oligotrophic and extreme cold habitats on the planet Earth and the aforementioned parameters are known to influence microbial diversity. In the Himalayan regions and Arctic, microbial diversity studies were restricted only to soil, ice, water and sediment whereas in Antarctica in addition sea-ice, fast-ice, sediment, cyanobacterial mats, sub-glacial lake water, cryptoendolithic sand stones, air samples, ice cores etc. were also studied. Among all the habitats from the three geographic locations, microbial abundance in soil was found to be highest, followed by sediment, water and ice. The bacterial abundance was lowest in Arctic $\left(5.2 \times 10^{4}\right.$ to $2.5 \times 10^{5} \mathrm{cfug}^{-1}$ soil) and highest in Himalayan regions $\left(4.2 \times 10^{7}\right.$ to $30.7 \times 10^{8} \mathrm{cfug}^{-1}$ soil $)$.

\section{Antarctica}

In Antarctica, abundance ranged from $0.2 \times 10^{2}$ to $0.6 \times 10^{12}$ cells $\mathrm{g}^{-1}$ of ice (Carpenter et al., 2000; Priscu et al., 1999; Delille and Gleizon, 2003; Shivaji et al.,
2004; Shivaji et al., 2013c), $0.2 \times 10^{2}$ to $10^{7}{\text { cells } \mathrm{ml}^{-1}}^{-1}$ of water (Lo Giudice et al., 2012) and $8 \times 10^{6}$ to $2.4 \times 10^{7}$ cells $\mathrm{g}^{-1}$ of sediment (Stibal et al., 2012) and $10^{5}$ to $10^{10}$ cells $\mathrm{g}^{-1}$ of soil (Shivaji et al., 1988; 1989a, 1989b; Aislabie et al., 2009). The numbers were also abundant in cyanobacterial mats (Reddy et al., 2000, 2002a, 2002b, 2003a, 2003b, 2003c, 2003d, 2004) and have been reviewed by Shivaji and Reddy (2009) and Chattopadhyay et al. (2014). In Antarctica, higher bacterial abundance corresponded with high in situ sea-salt $\mathrm{Na}^{+}$and dust concentration, suggesting that bacteria might have been transported and deposited into ice along with dust particles and marine aerosols (Antony et al., 2012b).

\section{Arctic}

The bacterial abundance in major habitats from Arctic region was comparable to that observed in Antarctica and it ranged from 1.2 to $2.3 \times 10^{7}$ cells g $^{-1}$ of sediment (Forschner et al., 2009), $5.2 \times 10^{4}$ to $1.7 \times 10^{9}$ cells g $^{-1}$ of permafrost (Hansen et al., 2007), $0.9 \times 10^{3}$ to $2.4 \times 10^{6}$ cells ml ${ }^{-1}$ of ice (Møller et al., 2011) and in case of water the abundance was $5 \times 10^{5}$ cells $\mathrm{ml}^{-1}$ (Møller et al., 2011).

*AuthorforCorrespondence: E-mail: shivas@lvpei.org; shivas@ccmb.res.in; mkc@ccmb.res.in; gsnr@ccmb.res.in 


\section{Himalayan Glaciers}

In the Himalayan glaciers the total bacterial abundance was low in case of water $\left(1.1\right.$ to $25 \times 10^{4}$ cells ml-1) (Liu et al., 2011) and higher in case of sediments wherein it ranged from $0.9 \times 10^{7}$ to $30.7 \times 10^{8}$ cell per gram sediment (Shivaji et al., 2011b; Pradhan et al., 2010; Srinivas et al., 2011).

\section{Bacterial Diversity of Antarctica, Arctic and Himalayas at the Phyla Level}

Cultured bacteria constitute only a miniscule fraction $(<1 \%)$ of the total diversity and thus enumerating their abundance at taxonomic levels would not be correct. Nevertheless one could list their occurrence and diversity at various taxonomic levels without emphasizing on their abundance. The cultivable bacterial diversity was explored extensively from various habitats of Antarctica, Arctic and Himalayan glaciers such as soil, water, algal mats, ice and sediments (reviewed by Shivaji and Reddy, 2009; Chattopadyay et al., 2014). The most commonly occurring bacteria were affiliated to Proteobacteria, Cytophaga-Flavobacterium-Bacteriodetes, Actinobacteria and Firmicutes and the less common were communities belonging to Deinococcusthermus and Spirochaetes (Chattopadyay et al., 2014). Members of Epsilonproteobacteria were absent (Reddy et al., 2016). Antony et al. (2012a) studied bacterial diversity in an ice core from coastal Dronning Maud Land, East Antarctica and fourteen bacterial isolates belonging to the genera Methylobacterium, Brevundimonas, Paenibacillus, Bacillus and Micrococcus were retrieved. Among the Bacillus species, Bacillus aryabhattai which has been reported only from the upper stratosphere, was isolated and is the first record from the Earth's surface. It was also observed that the diversity of retrievable heterotrophic bacteria in Kongsfjorden, an Arctic fjord was represented by Firmicutes, Actinobacteria, Proteobacteria, and Bacteroidetes and observed that the composition of heterotrophic bacterial community was linked to the changes in the water masses and/or phytoplankton bloom dynamics occurring in Arctic summer (Sinha et al., 2017).

Novel Bacterial Genera and Species from Antarctica, Arctic, Himalayas and Stratosphere

Several new species of bacteria have been described from Antarctica, Arctic, Himalayan glaciers and stratosphere (160, 67, 19 and 7 novel species respectively). Most of the new species were identified as belonging to already existing genera except a few which were assigned to new genera. So far, 37 novel genera have been described from Antarctica and 9 novel genera from Arctic (Table 1 and 2). Antony et al. (2009) based on phenotypic and molecular markers identified Cellulosimicrobium cellulans from Antarctic snow.

Studies on the bacterial diversity of the stratosphere have been very limited. Difficulties in sampling the stratosphere under aseptic conditions have been one of the limiting factors. Recent studies have reported several bacteria from air samples collected at an altitude of 10 to $41 \mathrm{~km}$ and seven new species have been reported (Table 3 ). No new genera have been reported from the Stratosphere (Shivaji et al., 2006; 2009) (Table 3). Several genera from the Arctic (Arcticibacter, Huanghella, Dasania and Augustibacter) and Antarctica (Actimicrobium, Antarcticimonas, Antarctobacter, Constrictibacter, Granulosicoccus, Marisediminicola, Methylosphaera, Pricia, Psychrosinus, Rhodoglobus, Rhodoligotrophos, Robiginito-maculum, Roseibaca, Roseicitreum, Sejongia, Subsaxibacter, Subsaximicrobium, Zhongshania and Oleispira) (Yakimov et al., 2003; Bowman et al., 1997) were endemic to Antarctica and have not been reported from any other geographic region. Endemism of a particular genus may depend on the physico-chemical nature of the habitat. Further, the observed commonality in diversity between the regions implies that geographic separation may not have a major role in influencing the diversity and supports the hypothesis that everything is everywhere but the environment selects (O'Mastay 2008). The best example is the genus Cryobacterium that was originally described from Antarctica but its representatives were later on, identified from several other cold habitats such as Arctic and Himalayas. Further, a novel family, Granulosicoccaceae, was reported from Antarctic water (Lee et al., 2007).

\section{Bacterial Diversity of Antarctica, Arctic and Himalayas by Non-culturable Approach}

\section{Antarctica}

Non-cultivable methods, such as 16S rRNA gene 
Table 1: Novel bacterial genera from various habitats of Antarctica and Arctic* assigned by polyphasic taxonomy

\begin{tabular}{|c|c|c|c|}
\hline S. No. & Novel genera & Habitat & 16S rRNA gene accession number \\
\hline & Antarctica & & \\
\hline & Alphaproteobacteria & & \\
\hline 1 & Antarctobacter heliothermus* & Lake water & Y11552 \\
\hline 2 & Constrictibacter antarcticus* & Rock & AB510913 \\
\hline 3 & Loktanella salsilacus & Mats & AJ440997 \\
\hline 4 & Rhodoligotrophos appendicifer* & Water & AB617575 \\
\hline 5 & Robiginitomaculum antarcticum* & Sea water & EF495229 \\
\hline 6 & Roseibaca ekhonensis* & Saline Water & AJ605746 \\
\hline 7 & Roseicitreum antarcticum* & Sediment & FJ196006 \\
\hline 8 & Roseisalinus antarcticus & Lake water & AJ605747 \\
\hline 9 & Roseovarius tolerans & Lake water & Y11551 \\
\hline \multirow[t]{2}{*}{10} & Staleyaguttiformis & Lake water & Y16427 \\
\hline & Betaproteobacteria & & \\
\hline 11 & Actimicrobium antarcticum* & Sea water & HQ699437 \\
\hline \multirow[t]{2}{*}{12} & Polaromonas vacuolata & Sea ice & $\mathrm{U} 14585$ \\
\hline & Gamaproteobacteria & & \\
\hline 13 & Granulosicoccus antarcticus\# & Sea water & EF495228 \\
\hline 14 & Methylosphaera hansonii* & Lake water & U67929 \\
\hline 15 & Oleispira antarctica & Sea water & AJ426420 \\
\hline 16 & Psychromonas antarcticus & Sediment & Y14697 \\
\hline 17 & Saccharospirillum impatiens & Lake water & AJ315983 \\
\hline \multirow[t]{2}{*}{18} & Zhongshania antarctica* & Sea water & FJ889619 \\
\hline & CFB group bacteria & & \\
\hline 19 & Aequorivita antarctica & Sea water & AY027802 \\
\hline 20 & Antarcticimonas flava* & Sea water & EF554365 \\
\hline 21 & Gelidibacter algens & Sea ice & U62914 \\
\hline 22 & Gillisia limnaea & Mats & AJ440991 \\
\hline 23 & Hymenobacter roseosalivarius & & \\
\hline Soil & Y18833 & & \\
\hline 24 & Lacinutrix copepodicola & Sea ice & AY 694001 \\
\hline 25 & Polaribacter filamentus & Sea ice & $\mathrm{U} 73726$ \\
\hline 26 & Psychroflexus torquis & Sea ice & U85881 \\
\hline 27 & Psychroserpens burtonensis & Sea ice & U62913 \\
\hline 28 & Sejongia antarctica* & Soil & AY553293 \\
\hline 29 & Subsaxibacter broadyi* & Sea ice & AY693999 \\
\hline \multirow[t]{2}{*}{30} & Subsaximicrobium wynnwilliamsii* & Sea ice & AY693997 \\
\hline & Firmicutes & & \\
\hline \multirow[t]{2}{*}{31} & Psychrosinus fermentans* & Water & DQ767881 \\
\hline & High G+C Gram-positives & & \\
\hline 32 & Cryobacterium psychrophilum & Soil & AJ544063 \\
\hline 33 & Friedmanniella antarctica & Soil & Z78206 \\
\hline
\end{tabular}




\begin{tabular}{|c|c|c|c|}
\hline 34 & Marisediminicola antarctica* & Sediment & GQ496083 \\
\hline 35 & Modestobacter multiseptatus & Soil & Y18646 \\
\hline \multirow[t]{3}{*}{36} & Rhodoglobus vestalii* & Water & AJ459101 \\
\hline & Arctic & & \\
\hline & Gamaproteobacteria & & \\
\hline \multirow[t]{2}{*}{37} & Dasania marina* & Sediment & AY771747 \\
\hline & Deltaproteobacteria & & \\
\hline 38 & Desulfofaba gelida & Sediment & AF099063 \\
\hline 39 & Desulfofrigus oceanense* & Sediment & AF099064 \\
\hline \multirow[t]{2}{*}{40} & Desulfotalea psychrophila* & Sediment & AF099062 \\
\hline & CFB group bacteria & & \\
\hline 41 & Arcticibacter svalbardensis* & Soil & JQ396621 \\
\hline 42 & Huanghella arctica* & Soil & JQ303016 \\
\hline \multirow[t]{2}{*}{43} & Polaribacter filamentus & Sea ice & U73726 \\
\hline & Fermicutes & & \\
\hline \multirow[t]{2}{*}{44} & Tumebacillus permanentifrigoris & Permafrost & DQ444975 \\
\hline & High G+C Gram-positives & & \\
\hline 45 & Angustibacter luteus & Soil & AB512285 \\
\hline
\end{tabular}

*Represent genera that are endemic to Antarctica or Arctic. From Chattopadhyay et al., 2014

metagenomics, indicated the occurrence of Alphaproteobacteria, Betaproteobacteria, Gammaproteobacteria, Deltaproteobacteria, Epsilonproteobacteria, CytophagaFlavobacterium-Bacteroidetes (CFB) group of bacteria, Actinobacteria, Firmicutes, Acidobacteria and Verrucomicrobia in Antarctica, Arctic and Himalayas albeit with different relative percentages. For instance, Firmicutes and Acidobacterium were clearly an abundant community in the Himalayan soils compared to Antarctica and Arctic and Alphaproteobacteria and Deltaproteobacteria were dominant in Antarctica and Arctic. In the Himalayan glaciers the bacterial diversity exhibited an altitude gradient with a gradual decline in the number of genera with increase in altitude.

In the Antarctic soils bacterial diversity varied with respect to soil type (Bottos et al., 2014; Shivaji et al., 2004) with Proteobacteria (47.0\%) dominating in Antarctic Peninsula soils and Actinobacteria and Bacteriodetes ( $42.0 \%$ and $31 \%$ respectively) in West Antarctic soils and transantarctic Mountain soils (Bottos et al., 2014) respectively. Shivaji et al. (2011a) observed stratification of bacteria with respect to oxygen requirement in Antarctic soils and also identified quite a few clones belonging to Caldiserica group, a thermophilic candidate phylum (Shivaji et al., 2004; Aislabie et al., 2006; 2013). Bowman et al. (2000) detected more than 200 distinct phylotypes in anoxic marine sediment with close to $31.0 \%$ belonging to a novel deep branch within the low GC Gram-positives. While Antony et al. (2016) identified a diverse assemblage of prokaryotic (Proteobacteria, Actinobacteria, Firmicutes, Bacteroidetes, Deinococcus-Thermus, Planctomycetes, Verrucomicrobia and Euryarchaeota) communities capable of producing the enzymes lipase, protease, amylase, $\beta$-galactosidase, cellulase, and/or lignin modifying enzyme in regions of East Antarctica, with respect to compounds present in snow and tested whether their functional signature reflected the snow environment.

As compared to soil and sediments bacterial diversity in the water is generally reduced (LaybournParry, 1997) and a shift in diversity is observed with depth wherein the dominant Bacteroidetes, Betaproteobacteria and Actinobacteria in the surface layers are replaced by Gammaproteo bacteria and unclassified bacteria in deeper zones as in McMurdo ice shelf, Victoria land and in the 
Table 2: Novel bacterial species from various habitats of Himalayas* assigned by polyphasic taxonomy

\begin{tabular}{|c|c|c|c|}
\hline S. No. & Novel species & Habitat & 16S rRNA gene accession number \\
\hline & Alphaproteobacteria & & \\
\hline 1 & Rhodobacter changlensis & Soil & AM399030 \\
\hline \multirow[t]{2}{*}{2} & Rhodobacter megalophilus & Soil & AM421024 \\
\hline & Deltaproteobacteria & & \\
\hline \multirow[t]{2}{*}{3} & Desulfovibrio psychrotolerans & Soil & AM418397 \\
\hline & CFB group bacteria & & \\
\hline \multirow[t]{2}{*}{4} & Dyadobacter hamtensis & Soil & AJ619978 \\
\hline & Firmicutes & & \\
\hline 5 & Bacillus cecembensis & Soil & AM773821 \\
\hline 6 & Exiguobacterium himgiriensis & Soil & JX999056 \\
\hline 7 & Exiguobacterium indicum & Soil & AJ846291 \\
\hline 8 & Paenibacillus glacialis & Soil & EU815294 \\
\hline 9 & Paenisporosarcina indica & Soil & FN646595 \\
\hline \multirow[t]{2}{*}{10} & Planococcus stackebrandtii & Soil & AY437845 \\
\hline & High G+C Gram-positives & & \\
\hline 11 & Actinoalloteichus spitiensis & Soil & AY426714 \\
\hline 12 & Dietzia kunjamensis & Soil & DQ156908 \\
\hline 13 & Agrococcus lahaulensis & Soil & AY972480 \\
\hline 14 & Kocuria himachalensis & Soil & AY987383 \\
\hline 15 & Leifsonia pindariensis & Soil & AM900767 \\
\hline 16 & Leifsonia kafniensis & & AM889135 \\
\hline 17 & Ornithinimicrobium kibberense & Soil & AY636111 \\
\hline 18 & Rhodococcus kroppenstedtii & Soil & AY726605 \\
\hline 19 & Cryobacterium roopkundensis & Soil & EF467640 \\
\hline
\end{tabular}

*From Chattopadhyay et al. (2014)

Amundsen sea polyna (Archer et al., 2014; Kim et al., 2014). Prabagaran et al. (2007) demonstrated dynamic change in bacterial community following hydrocarbon contamination of sea water which revealed that genera Psychrobacter, Arcobacter, Formosa, Polaribacter, Ulvibacter and Tenacibaculum are present in hydrocarbon contaminated water and the abundance of Sulfitobacter group was high in sea water and decreased in contaminated seawater.

In a recent study, Singh et al. (2015a) studied the response of bacterio plankton to iron fertilization of the Southern Ocean, Antarctica based on metagenome approach. More than $97.35 \%$ of the sequences represented four bacterial lineages i.e. Alphaproteobacteria, Gammaproteobacteria,
Bacteroidetes and Firmicutes and confirmed their role in scavenging of phytoplankton blooms induced following iron fertilization. In addition, this study identified three unique phylogenetic clusters LOHAFEX Cluster 1 (affiliated to Bacteroidetes), 2 and 3 (affiliated to Firmicutes) which were not detected in any of the earlier studies on iron fertilization (Fig. 1). Further these clusters varied in their response to iron fertilization. For instance LOHAFEX Cluster 2 increased in abundance following iron fertilization which corresponded with phytoplankton bloom whereas LOHAFEX Cluster 3 disappeared after iron fertilization implying that high iron concentration may not be conducive for their survival (Singh et al., 2015a).

In sea ice Gammaproteobacteria, 


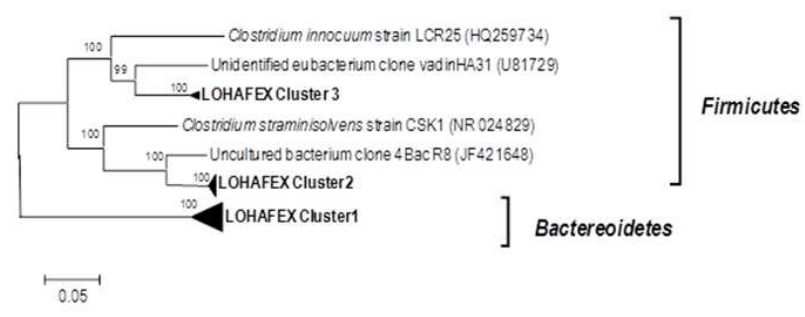

Fig. 1: Phylogenetic affiliation of Lohafex cluster1, Lohafex cluster 2 and Lohafex cluster 3 with Firmicutes and Bacteroidetes. Cluster 1 had 12 OTUs represented by 547 clones, Cluster 2 had 9 OTUs with 741 clones and Cluster 3 had 3 OTUs with 407 clones respectively

Alphaproteobacteria and Bacteriodetes are the predominant groups (Bowman et al., 1997; Kuhn et al., 2014). Temporal community analyses over a period of two years indicated a shift in community wherein Acinetobacter and Cohnella (Firmicutes) replaced Paenibacillus and Jeotgalibacillus in a span of two years (Doyle et al., 2013).

\section{Arctic}

The soil microbial communities are very similar to that observed in Antarctica. In soil, sediment, permafrost and ice genera belonging to the class Proteobacteria are most dominating and members of the class Actinobacteria, Firmicutes and Bacteriodetes contribute 3 to $25 \%$ (Collins et al., 2010; Wilhelm et al., 2011). In addition,
Gammaproteobacteria, Verrucomicrobia, Gemmatimonadetes and Deltaproteobacteria were also reported. The bacterial communities did not show any response to intermittent flow in water tracks over high Arctic permafrost (Steven et al., 2013). It was also observed that low $\mathrm{pH}$ supported the Proteobacteria at the expense of Acidobacteria and high pH supported Bacteriodetes (Ganzert et al., 2014). Sea-ice contained bacterial lineages that belonged to Proteobacteria, Bacteroidetes, Planctomycetes and Chloroflexi (Junge et al., 2002; Brinkmeyer et al., 2003; Bottos et al., 2008) and sea water harboured significant proportions of Proteobacteria (>50\%) and Bacteriodetes (25\%) and Actinobacteria and Verrucomicrobia were present below 25\% (Kirchman et al., 2010). Interestingly, a seasonal variation in bacterial abundance and change in phylotypes (belonging to the phyla Firmicutes, Actinobacteria, Proteobacteria, and Bacteroidetes) was observed in Kongsfjorden, an Arctic fjord (Sinha et al., 2017).

\section{Himalayan Glaciers}

The three habitats, soil, water and sediments from the Pindari, Kafni and Roopkund glaciers shared common taxa affiliated to Acidobacteria, Actinobacteria, Bacteroidetes, Chloroflexi, Chlamydiae, Firmicutes, Nitrospirae, Proteobacteria and Verrucomicrobia. However,

Table 3: Novel bacterial species from Stratospheric air samples assigned by polyphasic taxonomy

\begin{tabular}{|c|c|c|c|}
\hline Height (Kms) & Strain & Identity based on $16 \mathrm{~S}$ rRNA gene similarity (\%) & Year \\
\hline $24.10-38.87$ & $(24 \mathrm{~K}$ and $28 \mathrm{~K})$ & Bacillus aerius* & 2001 \\
\hline 28.0 & $(28 \mathrm{~K})$ & Bacillus aerophilus* & 2001 \\
\hline $39.65-41.06$ & $(41 \mathrm{KF} 2 \mathrm{a})$ & Bacillus stratosphericus* & 2001 \\
\hline $39.65-41.06$ & $(41 \mathrm{KF} 2 \mathrm{~b})$ & Bacillus altitudinus* & 2001 \\
\hline $27-30$ & (B3W22) & Bacillus isronensis* & 2005 \\
\hline $40-41.4$ & (B8W22) & Bacillus aryabhattai* & 2005 \\
\hline $40-41$ & (pVAS-1) & Janibacter hoylei* & 2005 \\
\hline $35-40$ & (B5W22-1) & Micrococcus flavus (99) & 2005 \\
\hline $35-40$ & (B5W22-2) & Streptomyces maritimus (99) & 2005 \\
\hline $20-24$ & (PVAS-8 and 5) & Stenotrophomonas rhizophila (99) & 2005 \\
\hline $30-35$ & (PVAS-4) & Acinetobacter radoresistense (100) & 2005 \\
\hline $35-40$ & (PVAS-6) & Acinetobacter calcooaceticus (99) & 2005 \\
\hline $35-40$ & (PVAS-10) & Bacillus pumilus (99) & 2005 \\
\hline $40-41$ & (PVAS-2 and 3) & Methylobacterium chloromathanicum (99) & 2005 \\
\hline
\end{tabular}


sediments from the glaciers differed in their diversity in that sediments from Kafni glacier contained clones affiliated to Spirochaetae and Tenericutes (Srinivas et al., 2011; Shivaji et al., 2011b) whereas samples from Pindari and Roopkund had sequences affiliated to Gemmatimonadetes and Planctomycetes. Gangwar et al., (2009) observed that Proteobacteria was the highest in soil (45 to 70\%) followed by Actinobacteria (10 to $86 \%$ ) and Bacteriodetes (6.4 to 28\%) (Gangwar et al., 2009; Srinivas et al., 2011). The difference in community composition in the three habitats studied so far can be attributed to the nature of the soil. So far 135 diverse genera were identified from various environments of Himalayas and the number of genera followed the trend Actinobacteria (28.0\%), Betaproteobacteria (21.5\%), Alphaproteobacteria (9.6\%), Gamaproteobacteria (8.9\%), Deltaproteobacteria (11.1\%), Bacteriodetes (11.1\%), Firmicutes (3.7\%), Acidobacteria (1.4\%), Verrucomicrobia (3.0\%) and Epsilonproteo bacteria (1.5\%). Further, Gupta et al., (2015) identified the rare taxa (Firmicutes, Nitrospirae, Armatimonadetes (former candidate division OP10), Planctomycetes, TM7, Chloroflexi and Deinococcus-Thermus) in Drass sector of Himalayan region and uniquely Acidobacteria $(32.1 \%)$ was the most dominant community.

\section{Unique Features of Bacteria from Antarctica, Arctic, Himalayas and Stratosphere}

A vast majority of the species isolated from Antarctica, Arctic and Stratosphere are psychrophilic. However, a few species like Alicyclobacillus pohliae $\left(42-60^{\circ} \mathrm{C}\right)$ (Imperio et al., 2008), Aneurinibacillus terranovensis $\left(20-55^{\circ} \mathrm{C}\right)$, (Allan et al., 2005), Anoxybacillus amylolyticus $\left(45-65^{\circ} \mathrm{C}\right)$ (Poliet al., 2006), Bacillus fumrioli $\left(25-55^{\circ} \mathrm{C}\right)$ (Logan et al., 2000), Brevibacillus levickii $\left(15-55^{\circ} \mathrm{C}\right)$ (Allan et al., 2005), Paenibacillus cineris $\left(8-50^{\circ} \mathrm{C}\right)$ and Paenibacillus cookie $\left(15-50^{\circ} \mathrm{C}\right)$ (Logan et al., 2004) are moderately thermophilic and interestingly all these species were isolated from soil. Further, $68 \%$ of novel species described so far are pigmented, indicating that pigmentation is a common phenomenon in Antarctic bacteria. Pigment is known to be involved in stress adaptation to low temperatures (Jaganadham et al., 1996; Jaganadham et al., 2000; Chattopadyay et al., 1997).
At the DNA level it was observed that the $16 \mathrm{~S}$ rDNA operons possessed specific psychrotolerant signatures such as the transitions from $\mathrm{C}$ and $\mathrm{G}$ to $\mathrm{T}$ and $\mathrm{A}$, higher uracil content and $\mathrm{G}: \mathrm{U}$ mismatches compared to mesophilic strains of Bacillus (Prüss et al., 1999; Lauro et al., 2007). Further swollen sporangia were observed in psychrophilic strains of the genus Bacillus compared to their nearest mesophilic counterparts (Abd El-Rahman et al., 2002; Larkin and Stokes, 1967; Priest et al., 1988). Bacillus cecembensis, a psychrophilic species from Himalayas contained $\mathrm{C}_{16: 1} \omega 7 \mathrm{c}$ alcohol in its membrane while it is absent in its nearest mesophilic neighbour (Reddy et al., 2008). In fact all the psychrophiles have a preponderance of unsaturated fatty acids compared to mesophilic counterparts. These bacteria also have cold active and heat labile enzymes (Ray et al., 1992; Reddy et al., 1994; Chattopadhyay et al., 1995) and have genes that are essential for their survival at low temperature (Singh et al., 2009; Singh and Shivaji, 2010; Sundareswaran et al., 2010). Some other aspects of adaptation to low temperature are highlighted in the following section of this article.

\section{Strategies Involved in Cold Adaptation}

Studies have indicated that psychrophilic bacteria adapt to low temperatures by adopting multiple strategies such as their ability to miniaturize and undergo fragmentation as in an Arctic strain of Psychrobacter (Ewert and Deming, 2014), ability to produce cold-tolerant and/or thermolabile enzymes (Feller and Gardaí, 2003; Singh et al., 2014a) and ability to sense changes in temperature by modulating membrane fluidity (Ray et al., 1994). Studies have demonstrated that preferential synthesis of membrane-fluidizing fatty acids (unsaturated, shortchain and anteiso-fatty acids) coupled with involvement of some carotenoid pigments appear to help them in the homeoviscous adaptation of membrane fluidity (Chintalapati et al., 2004, Chattopadhyay and Jagannadham, 2001). Temperature-dependent changes in the DNA topology is also postulated to play an important role in sensing ambient temperature (Shivaji and Prakash, 2010). The ability of some bacteria, isolated from the extreme cold habitats, to continue both catabolism and anabolism at sub-zero temperatures has been demonstrated (Sengupta and Chattopadhyay, 2013). It has also been demonstrated that bacteria preferentially transcribe cold-inducible 
genes at low temperature as a survival strategy and cold-inducible promoters regulate the expression of such genes at low temperature. In a review, Singh et al. (2014b) have compiled all the advances on cold inducible promoters and regulation of gene expression at low temperature. Ability to transcribe and translate (Ray et al., 1998) and re-initiation of replication (Sinha et al., 2013) at cold temperatures is a characteristic feature of cold adaptation. Degradation of RNA is a crucial step in the regulation of gene expression and the RNA-degradosome, a protein complex involved in RNA degradation, was found to be substantially different in an Antarctic bacterium compared to those in E. coli (Purusharth et al., 2007). In Methanolobus psychrophilus R15, exosome-mediated RNA degradation at low temperature was accelerated (Chen et al., 2012). In natural environments bacteria are most often challenged with more than one stress factor. Consequently, they have to adapt to more than one stressor for survival (Rothschild and Mancinelli, 2001). Association between tolerance of bacteria to low temperature and some other stress factors was highlighted earlier (Chattopadhyay, 2008). Adaptation of some Antarctic isolates to high osmotic stress, high $\mathrm{pH}$ and high oxidative stress besides freezing, was also demonstrated and the prospective role of an enzyme in tolerance of one isolate to multiple stress factors was also evidenced (Sengupta et al., 2015).

\section{Specific Genes Involved in Cold Adaptation}

Attempts have been made to ascertain whether a single gene or multiple genes are required for growth at low temperature. Pseudomonas syringae Lz4W, a psychrophilic bacterium capable of growing at temperatures between 2 and $30^{\circ} \mathrm{C}$, yielded 30 coldsensitive mutants following transposon mutagenesis. Two of these mutants CSM1 and CSM2 were characterized and the results indicated that both had a single transposon insertion. In CSM1 the gene trm $\mathrm{E}$ coding for tRNA modification GTPase was disrupted whereas in CSM2 the gene $A A T$ coding for aspartate aminotransferase was disrupted. In both the mutants growth was retarded when cultured at $4^{\circ} \mathrm{C}$ but not when it was cultured at $22^{\circ} \mathrm{C}$ and $28^{\circ} \mathrm{C}$ compared to the growth of wild-type cells. Both these genes were cold-inducible and plasmid-mediated complementation of the genes to the mutants alleviated the coldsensitive phenotype of the mutants (Singh and Shivaji, 2010; Singh et al., 2010; Sundareswaran et al., 2010).
Earlier studies have also indicated that pnp (encoding polynucleotide phosphorylase), oppA (involved in the transport of oligo-nucleotides) and $\operatorname{rec} D$ have been identified as genes required for low-temperature growth. Presence of antifreeze proteins could also be a strategy to overcome freezing as demonstrated in Arctic cryoconite bacteria (Singh et al., 2014c).

\section{Lessons from Genome Sequencing of Psychrophiles}

Next-generation sequencing (NGS) has facilitated whole-genome sequencing of multiple organisms from different and distinct habitats and has helped to generate specific genomic information so as to understand and appreciate unique features of organisms such as their adaptation to extreme environments. For instance the presence of coldresistant proteins, cold-shock protein, soluble acylACP desaturase, ATP-dependent RNA helicase, DEAD/DEAH box family proteins, putative ribonuclease $\mathrm{H} 1$ are examples of proteins involved in cold resistance in polar microbial genomes. Based on the genome sequence of psychrophilic Pseudomonas extremaustralis (Raiger et al., 2015) genes required for osmoregulation, cold adaptation, exopolysaccharide production and degradation of complex compounds were detected. In addition genes coding for cold-shock proteins (Csps) and cold acclimation proteins (Caps) were present only in Pseudomonas extremaustralis which is a psychrophile and not in P. syringae pv. syringae $\mathrm{B} 278 \mathrm{a}$ and $P$. aeruginosa $\mathrm{PAO} 1$, which are mesophiles. Thus, it was suggested that these proteins contribute to cold adaptation of $P$. extremaustralis. We and others have recently reported the genome sequence of a number of psychrophiles from different cold habitats like Antarctica (Sreenivas et al., 2014; Reddy et al., 2013, 2014; Kumar et al., 2013a,b), Arctic (Shivaji et al., 2013a; 2013b; Kumar et al., 2013a; Kapseet al., 2017; Singh et al., 2016), Himalayan glaciers (Reddy et al., 2014) and Stratosphere (Shivaji et al., 2012). A comparative genome analysis of Csps in the psychrophilic Sphingobacterium antarcticum, Oceanisphaera arctica and Exiguobacterium indicum indicated that CspA was present in all of them, Csp C, D, E and G were present in at least one of the 3 isolates whereas Csp B and I were absent (unpublished). The implications of this observation with respect to cold adaptation warrant further studies. 
Draft genome sequence of a lake-isolate of Hymenobacter, tolerant to ultraviolet radiation and oxidative stress besides low temperature, was published some time back (Koo et al., 2014). Comparative genomics also suggested a decrease in charged amino acids in psychrophiles when compared with mesophiles and thermophiles. In a recent study when the genomes of Arctic and Antarctic Octadecabacter arcticus and O. antarcticus were compared high genome plasticity was observed and they possessed genes representing a new type of xanthorhodopsins as an adaptation to icy environments.

\section{Biotechnological Implications}

Microbes are crucial in the cycling of $\mathrm{C}$ and other elements such as $\mathrm{N}, \mathrm{S}$, and $\mathrm{P}$ and play an important role in transformation of dissolved organic matter in Antarctica and other regions (Antony et al., 2017). In an earlier study (Anthony et al., 2012b) demonstrated that carbon utilization by bacterial communities in three surface snow samples from Antarctica collected along a coastal to inland transect utilized diverse substrates like carbohydrates, amino acids, amines, amides, complex polymers, etc. (Antony et al., 2012b). This activity is dependent on the enzymes associated with these organisms which are cold-active and/or thermolabile and such novel enzymes find widespread application in biotechnology industry. In the Arctic also similar organisms with lipase, protease, cellulase, amylase, and urease activities with potential industrial applications have been reported (Singh et al., 2016).

These novel enzymes have been exploited for food processing, for reducing viscosity of fruit juices at low temperature and in leather industries. A thermolabile phosphatase, obtained from an Antarctic bacterium and patented (HKTM) is active in neutral and alkaline $\mathrm{pH}$ and is useful in performing sequential steps in a single tube $v i z$, restriction enzyme digestion, dephosphorylation, enzyme inactivation, and ligation or end-labelling. A cold-active lipase, obtained by cloning a lipolytic gene from an Arctic bacterium (Rhodococcu ssp. AW25M09) in E. coli, has been found to retain activity at high $\mathrm{pH}$, organic solvents (acetonitrile, diethyl ether) and salt $(1 \mathrm{M} \mathrm{NaCl})$. Thus it appears to be an interesting candidate for industrial applications (De Santi et al., 2014). Such strains could also be useful in lipase-mediated biodiesel production (Moreno and Rojo, 2014). Bacteria occurring in Polar Regions could also serve as potential candidates for production of unique antimicrobial compounds (Liu et al., 2013; Fondi et al., 2014). Cold-adapted bacteria capable of degrading hydrocarbons are useful in waste water treatment (Margesin and Schinner, 2001) and they are found not only in oil contaminated soil but also in soil that has no history of oil contamination (Shukor et al., 2009). A number of genes responsible for hydrocarbon biodegradation (e.g. monooxygenases, dioxygenases) in different oilcontaminated sites (Powell et al., 2006) were also identified. Besides petroleum products, heavy metals are also degraded. A bacterial isolate from the South Shetlands Islands, Antarctica, tentatively identified as a Pseudomonas sp. was found to convert sodium molybdate or $\mathrm{Mo}^{6+}$ to molybdenum blue (Ahmad et al., 2013). Microorganisms having the capacity to degrade Polychlorinated biphenyls (PCBs) have also been isolated from both the Arctic and Antarctic regions (Master and Mohn, 1998; De Domenico et al., 2004). It has been possible to improve the coldtolerance of the mesophilic E. coli by cloning the genes encoding two chaperonin proteins obtained from an Antarctic organism (Ferrer et al., 2003) and also by cloning a gene encoding an antifreeze protein occurring in a cold-tolerant plant (Deng et al., 2014). The use of such genetically engineered microorganisms with high capacity to degrade pollutants appears to be an attractive option. The potential role of some molecules, which confer tolerance to more than one stressor, was discussed elsewhere (Chattoapdhyay, 2013). The multistress-protective potential of these molecules could find application in construction of genetically engineered sturdy bacterial strains, suitable for bioremediation in harsh environments. Some food-borne bacteria evolved with tolerance to various stress conditions (low temperature, low $\mathrm{pH}$, high salt) used for the preservation of food and thus pose serious threat to the health of the consumers. It might also be possible to design inhibitors of these molecules and use them for the safe preservation of food materials (Chattopadhyay, 2013).

\section{Conclusions}

Psychrophiles are a predominant community on the planet Earth and define the lower limits of temperature 
at which life forms survive and replicate. They need to be studied more intensively to understand their contribution to the ecosystem. Psychrophiles are a bioresource and could serve as workhorses for the biotech industry and improve the quality of life of human beings by contributing to agriculture, medicine and industry. Bioprospecting for biomolecules using cultivable bacteria and the metagenome approach need to be pursued with greater focus. Understanding the survival strategies of psychrophiles would help to

\section{References}

Abd El-Rahman HA, Fritze D, Spröer C and Claus D (2002) Two novel psychrotolerant species, Bacillus psychrotolerans sp. nov. and Bacillus psychrodurans sp. nov., which contain ornithine in their cell walls. Int J Syst Evol Microbiol 52 2127-2133

Ahmad SA, Shukor MY, Shamaan NA, Mac Cormack WP and Syed MA (2013) Molybdate reduction to molybdenum blue by an Antarctic bacterium Biomed Res Int 2013 871941

Aislabie J, Jordan S, Ayton J, Klassen JL, Barker GM and Turner S (2009) Bacterial diversity associated withornithogenic soil of the Ross Sea region, Antarctica Can J Microbiol 55 21-36

Aislabie J, Saul DJ and Foght JM (2006) Bioremediation of hydrocarbon-contaminated polar soils Extremophiles $\mathbf{1 0}$ 171-179

Aislabie JM, Lau A, Dsouza M, Shepherd C, Rhodes P and Turner SJ (2013) Bacterial composition of soils of the Lake Wellman area, Darwin Mountains, Antarctica Extremophiles 17 775-786

Allan RN, Lebbe L, Heyrman J, De Vos P, Buchanan CJ and Logan NA (2005) Brevibacillus levickii sp. nov. and Aneurinibacillus terranovensi ssp. nov., two novel thermoacidophiles isolated from geothermal soils of northern Victoria Land, Antarctica Int J Syst Evol Microbiol 55 1039-1050

Antony R, Krishnan KP, Laluraj CM, Thamban M, Dhakephalkar PK, Engineer AS and Shivaji S (2012a) Diversity and physiology of culturable bacteria associated with a coastal Antarctic ice core Microbiol Res 167 372-380

Antony R, Krishnan KP, Thomas S, Abraham WP and Thamban M (2009) Phenotypic and molecular identification of Cellulosimicrobium cellulans isolated from Antarctic snow Antonie Van Leeuwenhoek 96 627-634

Antony R, Sanyal A, Kapse N, Dhakephalkar PK, Thamban M unravel cellular and molecular mechanisms that are obligatory for the survival of life forms at freezing temperatures. Such a knowledge base would strengthen human efforts in agriculture in cold regions and may also address issues related to bioremediation in cold regions of the Earth. There is a need to carry out more comparative genome analysis of psychrophiles from different cold habitats so as to unravel the molecular basis of cold adaptation.

and Nair S (2016) Microbial communities associated with Antarctic snow pack and their biogeochemical implications. Microbiol Res 192 192-202

Antony R, Willoughby AS, Grannas AM, Catanzano V, Sleighter RL, Thamban M, Hatcher PG and Nair S (2017) Molecular Insights on Dissolved Organic Matter Transformation by Supraglacial Microbial Communities. EnvironSci Technol 51 4328-4337

Antony R, Mahalinganathan K, Krishnan KP and Thamban M (2012b) Microbial preference for different size classes of organic carbon: A study from Antarctic snow Environ Monit Assess 184 5929-5943

Archer SD, McDonald IR, Herbold CW and Cary SC (2014) Characterisation of bacterioplankton communities in the meltwater ponds of Bratina Island, Victoria Land, Antarctica FEMS Microbiol Ecol 89 451-464

Bottos EM, Vincent WF, Greer CW and Whyte LG (2008) Prokaryotic diversity of arctic ice shelf microbial mats Environ Microbiol 10 950-966

Bottos EM, Woo AC, Zawar-Reza P, Pointing SB and Cary SC (2014) Airborne bacterial populations above desert soils of the McMurdo Dry Valleys, Antarctica Microb Ecol 67 120-128

Bowman JP, McCammon SA, Brown MV, Nichols DS, McMeekin TA (1997) Diversity and association of psychrophilic bacteria in Antarctic sea ice Appl Environ Microbiol 63 3068-3078

Bowman JP, Rea SM, McCammon SA and McMeekin TA(2000) Diversity and community structure within anoxic sediment from marine salinity meromictic lakes and a coastal meromictic marine basin, Vestfold Hills, Eastern Antarctica Environ Microbiol 2 227-237

Brinkmeyer R, Knittel K, Jüurgens J, Weyland H, Amann R and Helmke E (2003) Diversity and structure of bacterial communities in Arctic versus Antarctic pack ice Appl Environ Microbiol 69 6610-6619 
Carpenter EJ, Lin S and Capone DG (2000) Bacterial activity in South Pole snow Appl Environ Microbiol 66 4514-4517

Chattopadhyay MK and Jagannadham MV (2001) Maintenance of membrane fluidity in Antarctic bacteria Polar Biol 24 386-388

Chattopadhyay MK (2008) Cryotolerance in bacteria: Interlink with adaptation to other stress factors Trends Microbiol 16455

Chattopadhyay MK (2013) Multistress-protective proteins in bacteria: In Molecular Biology of Bacteria pp 55-61, Nova Science Publishers Inc, NY, USA

Chattopadhyay MK, Jagannadham MV, Vairamani M and Shivaji S (1997) Carotenoid pigments of an Antarctic psychrotrophic bacterium Micrococcus roseus: temperature dependent biosynthesis, structure and interaction with synthetic membranes Biochem Biophys Res Commun 239 85-90

Chattopadhyay MK, Reddy GSN and Shivaji S (2014) Psychrophilic bacteria: Biodiversity, Molecular basis of cold adaptation and biotechnological implications Curr Biotech 3 100-116

Chattopadhyay MK, Uma Devi K, Gopisankar Y and Shivaji S (1995) Thermolabile alkaline phosphatase from Sphingobacterium antarcticus, a psychrotrophic bacterium from Antarctica. Polar Biol 15 215-219

Chen Z, Yu H, Li L, Hu S and Dong X (2012) The genome and transcriptome of a newly described psychrophilic archaeon, Methanolobus psychrophilus R15, reveal its cold adaptive characteristics Environ Microbiol Rep 4 633-641

Chintalapati S, Kiran MD and Shivaji S (2004) Role of membrane lipid fatty acids in cold adaptation Cell Mol Biol 50 631642

Collins RE, Rocap G and Deming JW (2010) Persistence of bacterial and archaeal communities in sea ice through an Arctic winter Environ Microbiol 12 1828-1841

De Domenico M, Lo Giudice A, Michaud L, Saitta M and Bruni V (2004) Diesel oil and PCB-degrading psychrotrophic bacteria isolated from Antarctic seawaters (Terra Nova Bay, Ross Sea) Polar Research 23 141-146

De Santi C, Tedesco P, Ambrosi no L, Altermark B, Willassen NP and de Pascale D (2014) A new alkaliphilic cold-active esterase from the psychrophilic marine bacterium Rhodococcus sp. functional and structural studies and biotechnological potential Appl Biochem Biotechnol 172 3054-3068

Delille D and Gleizon F (2003) Distribution of enteric bacteria in Antarctic seawater surrounding the Port-aux-Français permanent station (Kerguelen Island). Mar Pollut Bull 46 1179-1183

Deng LQ, Yu HQ, Liu YP, Jiao PP, Zhou SF, Zhang SZ, Li WC and $\mathrm{Fu} F L(2014)$ Heterologous expression of antifreeze protein gene AnAFP from Ammopiptanthus nanus enhances cold tolerance in Escherichia coli and tobacco Gene 539 132-140

Doyle SM, Montross SN, Skidmore ML and Christner BC (2013) Characterizing microbial diversity and the potential for metabolic function at $-15^{\circ} \mathrm{C}$ in the Basal ice of taylor glacier, antarctica Biology 2 1034-1053

Ewert $M$ and Deming JW (2014) Bacterial responses to fluctuations and extremes in temperature and brine salinity at the surface of Arctic winter sea ice FEMS Microbiol Ecol 89 476-489

Feller G and Gerday C (2003) Psychrophilic enzymes: Hot topics in cold adaptation Nat Rev Microbiol 1 200-208

Ferrer M, Chernikova TN, Yakimov MM, Golyshin PN and Timmis KN (2003) Chaperonins govern growth of Escherichia coli at low temperatures Nat Biotechnol 21 1266-1267

Fondi M, Orlandini V, Perrin E, Maida I, Bosi E, PapaleoMC, Michaud L, Lo Giudice A, de Pascale D, Tutino ML, Liò $P$ and Fani R (2014) Draft genomes of three Antarctic Psychrobacter strains producing antimicrobial compounds against Burkholderia cepacia complex, opportunistic human pathogens Mar Genomics 13 37-38

Forschner SR, Sheffer R, Rowley DC and Smith DC (2009) Microbial diversity in Cenozoic sediments recovered from the Lomonosov Ridge in the Central Arctic basin Environ Microbiol 11 630-639

Gangwar P, Alam SI, Bansod S and Singh L (2009) Bacterial diversity of soil samples from the western Himalayas, India Can J Microbiol 55 564-577

GanzertL, Bajerski F and Wagner D (2014) Bacterial community composition and diversity of five different permafrostaffected soils of Northeast Greenland FEMS Microbiol Ecol 89 426-441

Gupta P, Sangwan N, Lal R and Vakhlu J (2015) Bacterial diversity of Drass, cold desert in Western Himalaya, and its comparison with Antarctic and Arctic Arch Microbiol $197851-860$

Hansen AA, Herbert RA, Mikkelsen K et al. (2007) Viability, diversity and composition of the bacterial community in a high Arctic permafrost soil from Spitsbergen, Northern Norway Environ Microbiol 9 2870-2884

Imperio T, Viti C and Marri L (2008) Alicyclobacillus pohliae sp. 
nov., a thermophilic, endospore-forming bacterium isolated from geothermal soil of the north-west slope of Mount Melbourne (Antarctica) Int J Syst Evol Microbiol 58 221225

Jagannadham MV, Chattopadhyay MK and Shivaji S (1996) The major carotenoid pigment of a psychrotrophic Micrococcus roseus strain: Fluorescence properties of the pigment and its binding to membranes Biochem Biophys Res Commun 220724-728

Jagannadham MV, Chattopadhyay MK, Subbalakshmi C, Vairamani M, Narayanan K, Rao CM and Shivaji S (2000) Carotenoids of an Antarctic psychrotolerant bacterium, Sphingobacterium antarcticus, and a mesophilic bacterium, Sphingobacterium multivorum Arch Microbiol 173 418-424

Junge K, Imhoff F, Staley T and Deming JW (2002) Phylogenetic diversity of numerically important Arctic sea-ice bacteria cultured at subzero temperature Microb Ecol 43 315-328

Kapse N, Singh P, Roy U, Singh SM and Dhakephalkar PK (2017) Insights into the psychrophilic and sea ice-specific lifestyle of Marinobacter sp. Strain AC-23: A Genomic Approach Genome Announc 5 e00134-17

Kim JG, Park SJ, Quan ZX, Jung MY, Cha IT, Kim SJ, Kim KH, Yang EJ, Kim YN, Lee SH and Rhee SK (2014) Unveiling abundance and distribution of planktonic Bacteria and Archaea in a polynya in Amundsen Sea, Antarctica Environ Microbiol 16 566-578

Kirchman DL, Cottrell MT and Lovejoy C (2010) The structure of bacterial communities in the western Arctic Ocean as revealed by pyrosequencing of 16S rRNA genes Environ Microbiol 12 1132-1143

Koo H, Ptacek T, Crowley M, Swain AK, Osborne JD, Bej AK and Andersen DT (2014) Draft genome sequence of Hymenobacter $\mathrm{sp}$. Strain IS2118, isolated from a freshwater lake in Schirmacher Oasis, Antarctica, reveals diverse genes for adaptation to cold ecosystems Genome Announc 2 e00739-14

Kuhn E, Ichimura AS, Peng V, Fritsen CH, Trubl G, Doran PT and Murray AE (2014) Brine assemblages of ultrasmall microbial cells within the ice cover of Lake Vida, Antarctica Appl Environ Microbiol 80 3687-3698

Kumar PA, Sreenivas A, Singh A and Shivaji S (2013a) Draft genome sequence of Winogradskyella psychrotolerans RS$3^{\mathrm{T}}$, isolated from the marine transect of Kongsfjorden, $\mathrm{Ny}$ Ålesund, Svalbard, Arctic Genome Announc 1 e00630-13

Kumar PA, Singh A, Sreenivas A, Begum Z, Reddy GSN and Shivaji S (2013b) Draft genome sequence of Leifsonia rubra CMS $76 \mathrm{r}^{\mathrm{T}}$, isolated from a cyanobacterial mat sample from a pond in Wright Valley, McMurdo, Antarctica. Genome Announc 1 e00633-13

Larkin JM and Stokes JL (1967) Taxonomy of psychrophilic strains of Bacillus J Bacteriol 94 889-895

Lauro FM, Chastain RA, Blankenship LE, Yayanos AA and Bartlett DH (2007) The unique 16S rRNA genes of piezophiles reflect both phylogeny and adaptation Appl Environ Microbiol 73 838-845

Laybourn-Parry J (1997) The microbial loop in Antarctic Lakes. Ecosystem processes in Antarctic ice-free landscapes (Eds: Howards-Williams C, Lyons WB and Hawes I) pp 231240. Balkema/Rotterdam/Brookfield, Rotterdam.

Lee K, Lee HK, Choi TH, Kim KM and Cho JC (2007) Granulosicoccaceae fam. nov., to include Granulosicoccus antarcticus gen. nov., sp. nov., a non-phototrophic, obligately aerobic chemoheterotroph in the order Chromatiales, isolated from Antarctic seawater J Microbiol Biotechnol 17 1483-1490

Liu JT, Lu XL, Liu XY, Gao Y, Hu B, Jiao BH and Zheng H (2013) Bioactive natural products from the antarctic and arctic organisms Mini Rev Med Chem 13 617-626

Liu Y, Yao T, Jiao N, Tian L, Hu A, Yu W and Li S (2011) Microbial diversity in the snow, a moraine lake and a stream in Himalayan glacier Extremophiles 15 411-421

Lo Giudice A, Caruso C, Mangano S, Bruni V, De Domenico M and Michaud L (2012) Marine bacterioplankton diversity and community composition in an antarctic coastal environment Microb Ecol 63 210-223

Logan NA, De Clerck E, Lebbe L, Verhelst A, Goris J, Forsyth G, Rodríguez-Díaz M, Heyndrickx M and De Vos P (2004) Paenibacillus cineris sp. nov. and Paenibacillus cookie sp. nov., from Antarctic volcanic soils and a gelatin-processing plant Int J SystEvol Microbiol 54 1071-1076

Logan NA, Lebbe L, Hoste B, Goris J, Forsyth G, Heyndrickx M, Murray BL, Syme N, Wynn-Williams DD and De Vos P (2000) Aerobic endospore-forming bacteria from geothermal environments in northern Victoria Land, Antarctica, and Candlemas Island, South Sandwich archipelago, with the proposal of Bacillus fumarioli sp. nov Int J Syst Evol Microbiol 50 1741-1753

Margesin R and Schinner F (2001) Biodegradation and bioremediation of hydrocarbons in extreme environments Appl Microbiol Biotechnol 56 650-663

Master ER and Mohn WW (1998) Psychrotolerant bacteria isolated from Arctic soil that degrade polychlorinated biphenyls at low temperatures Appl Environ Microbiol 64 4823-4829 
Møller AK, Barkay T, Abu Al-Soud W, Sørensen SJ, Skov H and Kroer N (2011) Diversity and characterization of mercuryresistant bacteria in snow, freshwater and sea-ice brine from the High Arctic FEMS Ecol 75 390-401

Moreno R and Rojo F (2014) Features of pseudomonads growing at low temperatures: another facet of their versatility Environ Microbiol Rep 6 417-426

O' Mastay MA (2008) Everything is everywhere but the environment selects: Ubiquitous distribution and ecological determinism in microbial biogeography Stud Hist Philos Biol Biomed Sci 39 314-25

Poli A, Esposito E, Lama L, Orlando P, Nicolaus G, de Appolonia F, Gambacorta A and Nicolaus B (2006) Anoxybacillus amylolyticus sp. nov., a thermophilic amylase producing bacterium isolated from Mount Rittmann (Antarctica) SystAppl Microbiol 29 300-307

Powell SM, Ferguson SH, Bowman J P and Snape I (2006) Using real-time PCR to assess changes in the hydrocarbondegrading microbial community in Antarctic soil during bioremediation Microb Ecol 52 523-532

Prabagaran SR, Manorama R, Delille D and Shivaji S (2007) Predominance of Roseobacter, Sulfitobacter, Glaciecola and Psychrobacter in seawater collected off Ushuaia, Argentina, Sub-Antarctica FEMS Microbial Ecol 59 342-355

Pradhan S, Srinivas TNR, Pindi PK, Hara Kishore K, Begum Z, Singh PK, Singh AK, Pratibha MS, Yasala AK, Reddy GSN and Shivaji S (2010) Bacterial biodiversity from Roopkund Glacier, Himalayan mountain ranges, India Extremophiles 14 377-395

Priest FG, Goodfellow M and Todd C (1988) A numerical classification of the genus Bacillus J Gen Microbiol 1341847-1882

Priscu JC, Adams EE, Lyons WB, Voytek MA, Mogk DW, Brown RL, McKay CP, Takacs CD, Welch KA, WolfCF, Kirshtein JD andAvci R (1999) Geomicrobiology of subglacial ice above Lake Vostok, Antarctica Science 286 2141-2144

Prüss BM, Francis K P, von Stetten F and Scherer S (1999) Correlation of $16 \mathrm{~S}$ ribosomal DNA signature sequences with temperature-dependent growth rates of mesophilic and psychrotolerant strains of the Bacillus cereus Group J Bacteriol 181 2624-2630

Purusharth RI, Madhuri B and Ray MK (2007) Exoribonuclease $\mathrm{R}$ in Pseudomonas syringae is essential for growth at low temperature and plays a novel role in the 3 '- end processing of 16 and 5 S ribosomal RNA J Biol Chem 282 1626716277

RaigerIustman LJ, Tribelli PM, Ibarra JG, Catone MV, Solar
Venero EC and López NI (2015) Genome sequence analysis of Pseudomonas extremaustralis provides new insights into environmental adaptability and extreme conditions resistance Extremophiles 19 207-220

Ray MK, Devi KU, Kumar GS and Shivaji S (1992) Extracellular protease from the antarctic yeast Candida humicola Appl Environ Microbiol 58 1918-1923

Ray MK, Kumar GS and Shivaji S (1994) Phosphorylation of membrane proteins in response to temperature in an Antarctic Pseudomonas syringae Microbiology $1403217-$ 3723

Ray MK, Kumar GS, Janiyani K, Kannan K, Jagtap P, Basu MK and Shivaji S (1998) Adaptation to low temperature and regulation of gene expression in Antarctic psychrotrophic bacteria J Biosci 23 423-435

Reddy GSN, Chattopadhyay MK and Shivaji S (2016) Biodiversity, adaptation and biotechnological importance of bacteria occurring in cold climates. In. Biotechnologyof Extremophiles: Advances and Challenges. (Eds:Pabulo H and Rampelotto) pp 47-81

Reddy GSN, Agarwal RK, MatsumotoGI and Shivaji S (2000) Arthrobacter flavus sp. nov., a psychrotropic bacterium isolated from a pond in Mc Murdo Dry Valley, Antarctica Int J Syst Evol Microbiol 50 1553-1561

Reddy GSN, Ara S, Singh A, Kumar Pinnaka A and Shivaji S (2013) Draft genome sequence of Psychrobacter aquaticus CMS $56^{\mathrm{T}}$, isolated from a cyanobacterial mat sample collected from water bodies in the McMurdo Dry Valley region of Antarctica Genome Announc 1 e00918-13

Reddy GSN, Matsumoto GI and Shivaji S (2003a) Sporosarcinamac murdoensis $\mathrm{sp}$. nov. from a cyanobacterial mat samples from a pond in the McMurdo dry valley, Antarctica Int J Syst Evol Microbiol 53 13631367

Reddy GSN, Matsumoto GI, Shuman P, Stackebrandt E and Shivaji S (2004) Psychrophilic Pseudomonas from Antarctica: Pseudomonas antarctica sp. nov., Pseudomonas meridianae sp. nov. and Pseudomonas proteolytica sp. nov Int J Syst Evol Microbiol 54 713-719

Reddy GSN, Prakash JSS, Matsumoto GI, Stackebrandt E and Shivaji S (2002a) Arthrobacter roseus sp. nov., a psychrotropic bacterium isolated from an Antarctic cyanobacterial mat sample Int J Syst Evol Microbiol 52 1017-1021

Reddy GSN, Prakash JSS, Prabahar V, Matsumoto GI, Stackebrandt E and Shivaji S (2003d) Kocuria polaris sp. nov., an orange pigmented psychrotrophic bacterium isolated from an Antarctic cyanobacterial mat sample Int $J$ 
Syst Evol Microbiol 53 183-187

Reddy GSN, Prakash JSS, Srinivas R, Matsumoto GI and Shivaji S (2003b) Leifsonia rubra sp. nov. and Leifsonia aurea sp. nov. psychrophiles from a pond in Antarctica Int $J$ Syst Evol Microbiol 53 977-984

Reddy GSN, Prakash JSS, Vairamani M, Prabhakar S, Matsumoto GI and Shivaji S (2002b) Planococcus antarcticus and Planococcus psychrophilus spp. nov. isolated from cyanobacterial mat samples collected from ponds in Antarctica Extremophiles 6 253-261

Reddy GSN, Raghavan PMU, Sarita NB, Prakash JSS, Nagesh N, Delille D and Shivaji S (2003c) Halomonas glacies sp. nov. isolated from fast ice of Adelie Land, Antarctica Extremophiles 7 55-61

Reddy GSN, Rajagopalan G, Shivaji S (1994) Thermolabile ribonuclease from Antarctic psychrotropic bacteria: Detection of the enzyme in various bacteria and purification from Pseudomonas fluorescens FEMS Microbiol Lett 122 211-216

Reddy GSN, Sreenivas A and Shivaji S (2014) Draft genome sequence Cryobacterium roopkundensis strain RuG17, isolated from a soil sample in the vicinity of Roopkund Lake, Himalayas, India Genome Announc 2 e01206-14.

Reddy GSN, Uttam A and Shivaji S (2008) Bacillus cecembensis sp. nov., a bacterium isolated from the Pindari glacier of the Himalayan mountain ranges, India Int J Syst Evol Microbiol 58 2330-2335

Rothschild LJ and Mancinelli RL (2001) Life in extreme environments Nature 409 1092-1101

Sengupta D, Sangu K, Shivaji S and Chattopadhyay MK (2015) Tolerance of an Antarctic bacterium to multiple environmental stressors Curr Microbiol 71 483-489

Sengupta D and Chattopadhyay MK (2013) Metabolism in bacteria at low temperature: A recent report J Biosci 38 14

Shivaji S and Prakash JS (2010) How do bacteria sense and respond to low temperature? Arch Microbiol 192 85-95

Shivaji S and Reddy GSN (2009) Bacterial biodiversity of Antarctica: conventional polyphasic and rRNA approaches. In: Polar Microbiology: The ecology, biodiversity and bioremediation potential of microorganisms in extremely cold environments (Eds: Bej A K, Aislabie J and Atlas RM) Taylor \& Francis group

Shivaji S, Ara S, Prasad S, Manasa BP, Begum Z, Singh A and Kumar Pinnaka A (2013b) Draft genome sequence of Arcticibactersval bardensis MN12-7T, a member of the family Sphingobacteriaceae isolated from an Arctic soil sample Genome Announc 1 e00484-13

Shivaji S, Ara S, Singh A and Kumar Pinnaka A (2013a) Draft genome sequence of Cyclobacterium qasimii M12-11B T, isolated from an Arctic marine sediment Genome Announc 1 e00642-13

Shivaji S, Ara S, Singh SK, Bandi S, Singh A and Pinnaka AK (2012) Draft genome sequence of Bacillus isronensis strain B3W22 isolated from the upper atmosphere $J$ Bacteriol 194 6624-6625

Shivaji S, Begum Z, Shiva Nageswara Rao SS, Vishnu Vardhan Reddy PV, Manasa P, Sailaja B, Prathiba MS, Thamban M, Krishnan KP, Singh SM and Srinivas TN (2013c) Antarctic ice core samples: culturable bacterial diversity Res Microbiol 164 70-82

Shivaji S, Chaturvedi P, Begum Z, Pindi PK, Manorama R, Ananth Padmanaban D, Shouche YS, Pawar S, Vaishampayan P, Dutt CBS, Datta GS, Manchanda RK, Rao UR, Bhargava PM and Narlikar JV (2009) Janibacter hoylei sp. nov., Bacillus isronensis sp. nov. and Bacillus aryabhattai sp. nov., isolated from cryotubes used for collecting air from the upper atmosphere Int J Syst Evol Microbiol 592977 2986

Shivaji S, Chaturvedi P, Suresh K, Reddy GSN, Dutt CBS, Wainwright M, Narlikar JV and Bhargava PM (2006) Bacillus aerius sp. nov., Bacillus aerophilus sp. nov., Bacillusstra tosphericus sp. nov. and Bacillus altitudinis sp. nov., isolated from cryogenic tubes used for collecting air samples from high altitudes Int J Syst Evol Microbiol 56 1465-1473

Shivaji S, Kumari K, Kishore KH, Pindi PK, Rao PS, Srinivas TN, Asthana R and Ravindra R (2011a) Vertical distribution of bacteria in a lake sediment from Antarctica by cultureindependent and culture-dependent approaches Res Microbiol 162 191-203

Shivaji S, Pratibha MS, Sailaja B, Hara Kishore K, Singh AK, Begum Z, Anarasi U, Prabagaran SR, Reddy GSN and Srinivas TN (2011b) Bacterial diversity of soil in the vicinity of Pindari glacier, Himalayan mountain ranges, India, using culturable bacteria and soil 16S rRNA gene clones Extremophiles 15 1-22

Shivaji S, Rao NS, Saisree L, Reddy GSN, Kumar GS and Bhargava PM (1989b) Isolates of Arthrobacter from the soils of Schirmacher Oasis, Antarctica PolarBiol 10 225-229

Shivaji S, Rao NS, Saisree L, Sheth V, Reddy GSN and Bhargava PM (1988) Isolation and identification of Micrococcus roseus and Planococcus sp. from Schirmacher Oasis, Antarctica J Biosci 113 409-414 
Shivaji S, Rao NS, Saisree L, Sheth V, Reddy GSN and Bhargava PM (1989a) Isolation and identification of Pseudomonas sp. from Schirmacher Oasis, Antarctica Appl Environ Microbiol 55 767-770

Shivaji S, Reddy GSN, Prasad RA, Kutty R and Ravenschlag K (2004) Bacterial diversity of a soil sample from Schirmacher Oasis, Antarctica Cell Mol Biol 50 525-536

Shukor MY, Hassan NA, Jusoh AZ, Perumal N, Shamaan NA, MacCormack WP and Syed MA (2009) Isolation and characterization of a Pseudomonas diesel-degrading strain from Antarctica J Environ Biol 30 1-6

Singh AK and Shivaji S (2010) A cold-active and a heat-labile tRNA modification GTPase from a psychrophilic bacterium Pseudomonas syringae (Lz4W) Res Microbiol 161 46-50

Singh AK, Pindi PK, Dube S, Sundareswaran VR and Shivaji S (2009) In the psychrophilic Pseudomonas syringae, trmE is important for low temperature growth Appl Environ Microbiol 75 4419-4426

Singh AK, Sad K, Singh SK and Shivaji S (2014b) Regulation of gene expression at low temperature: role of cold-inducible promoters Microbiology 160 1291-1296

Singh P, Hanada Y, Singh SM and Tsuda S (2014c) Antifreeze protein activity in Arctic cryoconite bacteria FEMS Microbiol Lett 351 14-22

Singh P, Kapse N, Arora P, Singh SM and Dhakephalkar PK (2015b) Draft genome of Cryobacterium sp. MLB-32, an obligate psychrophile from glacier cryoconite holes of high Arctic Mar Genomics 21 25-26

Singh P, Singh SM and Dhakephalkar P (2014a) Diversity, cold active enzymes and adaptation strategies of bacteria inhabiting glacier cryoconite holes of high Arctic Extremophiles 18 229-242

Singh P, Singh SM and Roy U (2016) Taxonomic characterization and the bio-potential of bacteria isolated from glacier ice cores in the High Arctic J Basic Microbiol 56 275-285

Singh SK, Kotakonda A, Kapardar RK, Kankipati HK, Rao PS, Sankaranarayanan PM, Vetaikorumagan SR, Reddy GSN, Nagappa R andShivaji S (2015a) Response of bacterioplankton to iron fertilization of the Southern Ocean, Antarctica Front Microbiol 6863

Sinha AK, Pavankumar TL, Kamisetty S, Mittal P and Ray MK (2013) Replication arrest is a major threat to growth at low temperature in Antarctic Pseudomonas syringae $\mathrm{Lz} 4 \mathrm{~W}$ Mol Microbiol 89 792-810

Sinha RK, Krishnan KP, Hatha AA, Rahiman M, Thresyamma DD and Kerkar S (2017) Diversity of retrievable heterotrophic bacteria in Kongsfjorden, an Arctic fjord Braz J Microbiol 48 51-61

Sreenivas A, Reddy GSN and Shivaji S (2014) Draft genome sequence of a psychrophilic bacterium Sphingomonas antarcticum 4BY, isolated from the soils of Schirmacher oasis, Antarctica Genome Announc 2 e00696-14

Srinivas TN, Singh SM, Pradhan S, Pratibha MS, Kishore KH, Singh AK, Begum Z, Prabagaran SR, Reddy GSN and Shivaji S (2011) Comparison of bacterial diversity in proglacial soil from Kafni Glacier, Himalayan Mountain ranges, India, with the bacterial diversity of other glaciers in the world Extremophiles 15 673-690

Stibal M, Hasan F, Wadham JL, Sharp MJ and Anesio AM (2012) Prokaryotic diversity in sediments beneath two polar glaciers with contrasting organic carbon substrates Extremophiles 16 255-265

Sundareswaran VR, Singh AK, Dube S and Shivaji S (2010) Aspartate aminotransferase is involved in cold adaptation in psychrophilic Pseudomonas syringae Arch Microbiol 192 663-672

Wilhelm RC, Niederberger TD, Greer C and Whyte LG (2011) Microbial diversity of active layer and permafrost in an acidic wetland from the Canadian High Arctic Can J Microbiol 57 303-315

Yakimov MM, Giuliano L, Gentile G, Crisafi E, Chernikova TN, Abraham WR, Lünsdorf H, Timmis KN and Golyshin PN (2003) Oleispira antarctica gen. nov., sp. nov., a novel hydrocarbonoclastic marine bacterium isolated from Antarctic coastal sea water Int J Syst Evol Microbiol 53 $779-85$. 